\title{
Symbolic trephinations and population structure
}

\author{
László Szathmáry ${ }^{+}$, Antónia Marcsik*
}

\author{
Department of Evolutionary Zoology and Human Biology, University of Debrecen, P.O.B. 3, Debrecen, H-4010 Hungary \\ *Department of Anthropology, University of Szeged, Hungary
}

The sample examined consists of 19 skulls with symbolic trephinations and 86 skulls without trepanations dated from the X century. Skulls were all excavated in the Great Hungarian Plain in the Carpathian Basin, which was occupied by the Hungarian conquerors at the end of the IX century. The variations of 12 cranial dimensions of the trephined skulls were investigated and compared to the skulls without trepanations after performing a discriminant analysis. The classification results evince that the variability of non-trephined skulls shows a more homogeneous and a more characteristic picture of their own group than the trephined samples, which corresponds to the notion, formed by archaeological evidence and written historical sources, of a both ethnically and socially differing population of the Hungarian conquerors. According to historical research, a part of the population was of Finno-Ugric origin, while the military leading layer of society can be brought into connection with Turkic ethnic groups. All the same, individuals dug up with rich grave furniture and supposed to belong to this upper stratum of society are primarily characterized by the custom of symbolic trephination, and, as our results demonstrate, craniologically they seem to be more heterogeneous.

Key words: symbolic trephinations - exogamy - early Hungarians - Carpathian Basin

Archaeological evidence and written historical sources equally refer to an obvious ethnical and social differentiation in the Hungarian conquerors' population at the time when they migrated from the Eastern-European steppes into the Carpathian Basin in Central-Europe in 895 A.D. A part of the population was of Finno-Ugric origin, however, the military leading layer of society has most frequently been brought into connection with Turkic ethnic groups by historical research. Primarily the individuals who are supposed to belong to this upper stratum of society and were found with rich grave furniture are characterized by the custom of symbolic trephination (Dienes 1972) (Figs 1, 2, 3, 4, 5).

The authors analyzed the variations of 12 cranial dimensions of all the skulls with symbolic trephinations excavated in the Great Hungarian Plain, an area that was occupied by the Hungarian conquerors at the earliest date, and afterwards they made a comparison of the skulls with symbolic trepanations and those without trephinations.

\section{MATERIALS AND METHODS}

The sample examined came from the Great Hungarian Plain in the Carpathian Basin and consisted of the cranial finds of more than 600 individuals altogether. The number of skulls which could be reconstructed biometrically was 52 without and 14 with trephinations in the case of males, whereas in the case of females, these numbers were 34 and 5, respectively. That is, we were able to analyze 86 skulls without trephinations and 19 skulls with trephinations (Table I).

Financial support: Széchenyi Terv no. 5/081

${ }^{+}$Corresponding author: szathmary@tigris.klte.hu

Received 20 July 2006

Accepted 16 October 2006
Adult skulls (23-x year) were examined according to 12 measurements:

(Key - v: variable; M: Martin’s number; Martin 1928)

v1 maximum cranial length (Martin 1)

v2 nasion-basion length (M5)

v3 maximum cranial breadth (M8)

v4 minimum frontal breadth (M9)

v5 basio-bregmatic height (M17)

v6 porion-bregmatic height (M20)

v7 bizygomatic breadth (M45)

v8 upper facial height (M48)

v9 orbital breadth (M51)

v10 orbital height (M52)

v11 nasal breadth (M54)

v12 nasal height (M55).

On reconstructing the missing values (Dear 1959) the skulls with symbolic trephinations and the skulls without trephinations were compared by using a univariate U-test and a discriminant analysis in the SPSS PC+ programme.

\section{RESULTS}

On the basis of the univariate U-statistics, the difference between the two groups was remarkable. In the case of males the two extracted brain case dimensions of the skulls without trephinations were significantly greater than those of the skulls trephined symbolically (Table II).

In the case of females it was also the extracted variables (v3, v8, v2) that might be significantly discriminant (Table III).

The classification results of the discriminant analyses (Table IV) pointed out that the variability of the non-trephined skulls showed a more homogeneous and a more characteristic picture of their group than the trephined samples. Thus we can assume that the basic population may have been characterized by endogamy, while exogamy may have tended to gain ground among trephined individuals to a higher degree. 


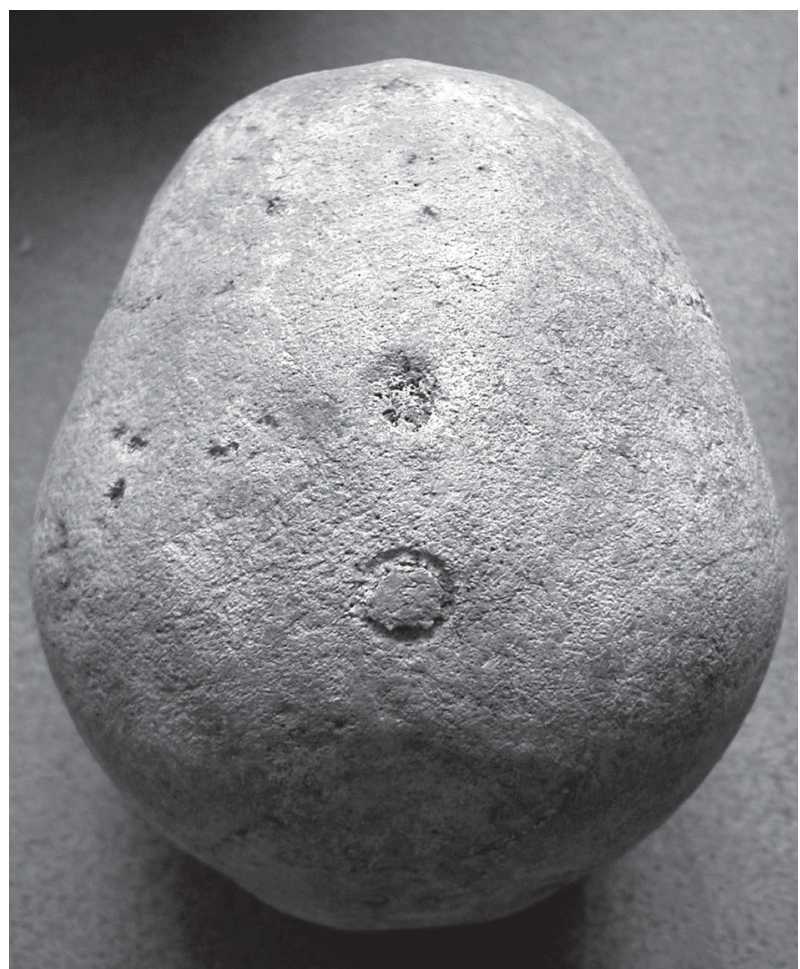

Fig. 1: finished and semi-finished (below) symbolic trephinations from grave 38 of a recent excavation in Hajdúdorog-Gyúlás (X century).

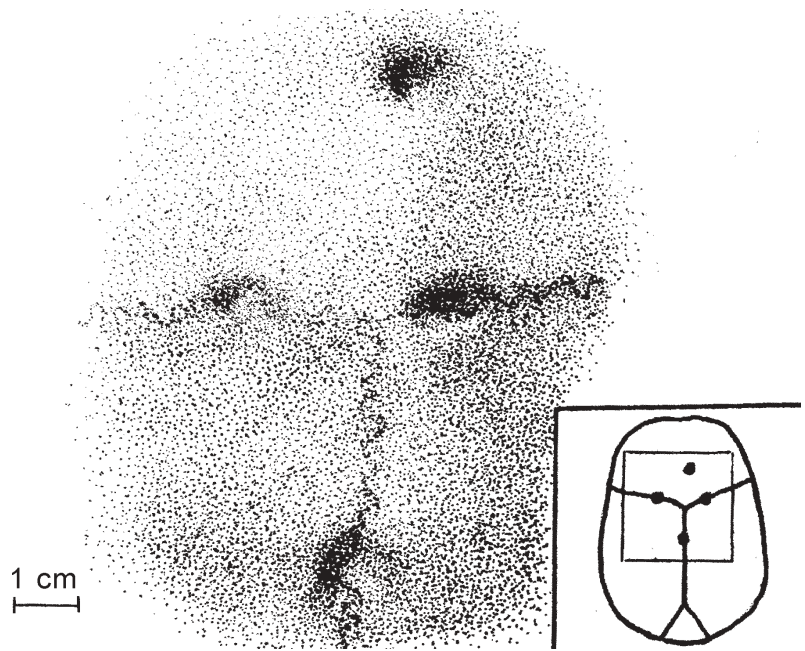

Fig. 2: quadruple symbolic trephinations from grave 6, Rakamaz (X century).

\section{DISCUSSION}

Different original variables were responsible for the segregation in either sex: the male skulls without trephinations measured longer and higher than the trephined skulls while the female non-trephined skulls were narrower with a lower face and with a shorter basicranium than the skulls with trephinations. On calculating the averages of the classification results of the two sexes, we could find that the identity of both groups was surprisingly high: $85 \%$ with the non-trephined skulls and $72 \%$ with the tre-

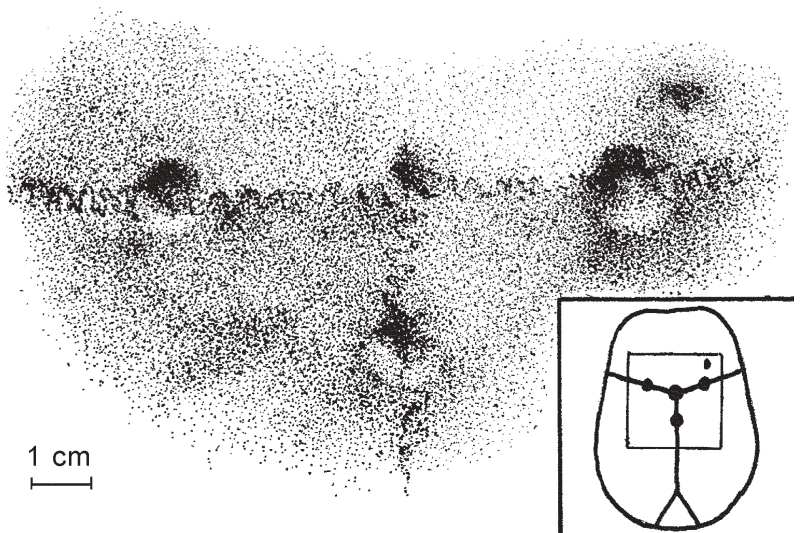

Fig. 3: quintuple symbolic trephinations from grave 13, Nagycserkesz (X century).
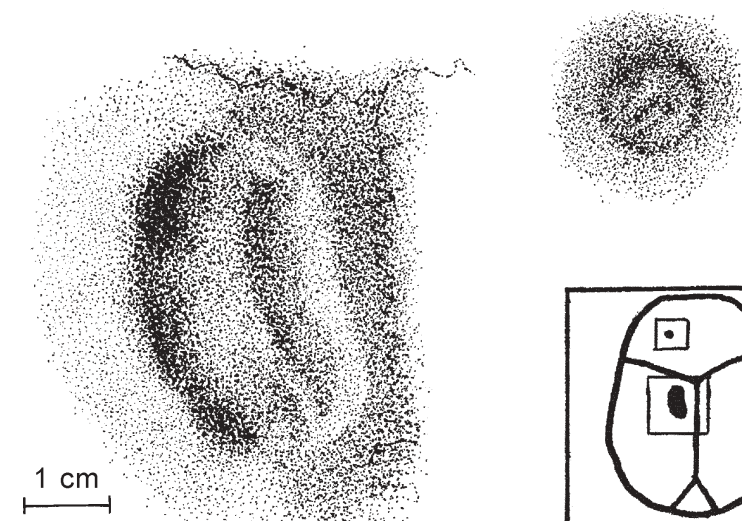

Fig. 4: symbolic trephinations from grave III, Rétközberencs (X century).

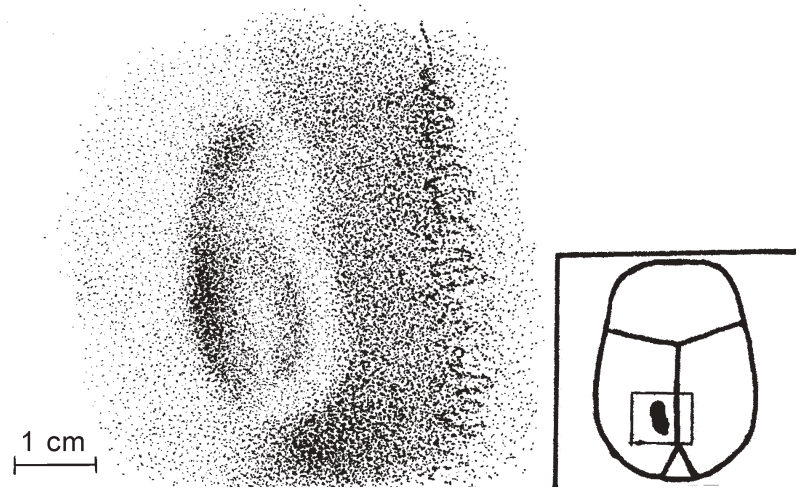

Fig. 5: symbolic trephinations from grave 17, Szabolcs (IX-X century).

phined ones. At the same time the frequency of overlapping between the groups was low: $15 \%$ with the nontrephined skulls and $28 \%$ with the trephined skulls.

These unexpected results refer to the fact that this special surgical custom may have functioned as a significant segregational factor either socially or ethnically in the population of X century Hungarians (c.f. Szathmáry 1980), and the custom of symbolic trepanation can be considered relevant to the extent of endogamy or exogamy. 
TABLE I

Number of adult skulls from the Great Hungarian Plain dating from the time of the Hungarian conquest (X century)

\begin{tabular}{|c|c|c|c|c|}
\hline \multirow[b]{2}{*}{ Localities } & \multicolumn{2}{|c|}{ Males } & \multicolumn{2}{|c|}{ Females } \\
\hline & $\begin{array}{l}\text { Skulls without } \\
\text { trephination }\end{array}$ & $\begin{array}{c}\text { Skulls with } \\
\text { symbolic trephination }\end{array}$ & $\begin{array}{l}\text { Skulls without } \\
\text { trephination }\end{array}$ & $\begin{array}{c}\text { Skulls with } \\
\text { symbolic trephination }\end{array}$ \\
\hline 1. Bodrogszerdahely (Streda nad Bodrogom) & 3 & - & - & - \\
\hline 2. Döge & - & - & 2 & - \\
\hline 3. Érpatak & - & - & - & 1 \\
\hline 4. Hencida & 2 & - & - & - \\
\hline 5. Ibrány-Esbóhalom & 15 & 2 & 14 & 1 \\
\hline 6. Karos & 3 & - & 1 & - \\
\hline 7. Kenézlõ & 1 & - & - & - \\
\hline 8. Nagycserkesz-Nádasi bokor & 5 & 1 & 2 & - \\
\hline 9. Nagyhalász & 1 & 2 & 1 & - \\
\hline 10. Nyíregyháza-Császárszállás & - & - & 1 & - \\
\hline 11. Rakamaz I & 1 & - & - & - \\
\hline 12. Rakamaz II & 4 & 1 & 1 & - \\
\hline 13. Rakamaz-Strázsa dombi dûlõ & 3 & 4 & 2 & - \\
\hline 14. Rétközberencs-Paramdomb & 2 & - & - & - \\
\hline 15. Szabolcs-Ref. parókia & 7 & 1 & 2 & 1 \\
\hline 16. Tiszaderzs & 1 & - & - & - \\
\hline 17. Tiszaeszlár-Bashalom I & - & - & 1 & - \\
\hline 18. Tiszaeszlár-Bashalom II & 2 & - & 2 & 1 \\
\hline 19. Tiszaeszlár-Újtelep & - & - & - & 1 \\
\hline 20. Tiszaeszlár-Vörösmarty u. 67 & - & - & 1 & - \\
\hline 21. Tiszavasvári-Aranykerti tábla & 2 & 1 & 4 & - \\
\hline 22. Tuzsér-Boszorkányhegy & - & 1 & - & - \\
\hline 23. Újfehértó-Micskepuszta & - & 1 & - & - \\
\hline Total & 52 & 14 & 34 & 5 \\
\hline
\end{tabular}

\section{TABLE II}

Distinction between the two types pointed out by a univariate test - Males (Great Hungarian Plain dating from the time of the Hungarian conquest $-\mathrm{X}$ century)

\begin{tabular}{lccr}
\hline Types & Parameters & v1 (M1) & v5 (M17) \\
\hline Non-trephined & mean s.d. & 185.9 & 138.6 \\
& & 7.0 & 3.2 \\
Symbolically trephined & mean s.d. & 179.3 & 134.5 \\
& & 5.4 & 3.8 \\
\hline
\end{tabular}

TABLE III

Distinction between the two types pointed out by a univariate test - Females (Great Hungarian Plain dating from the time of the Hungarian conquest $-\mathrm{X}$ century)

\begin{tabular}{lcccc}
\hline Types & Parameters & v3 (M8) & v8 (M48) & v2 (M5) \\
\hline Non-trephined & mean s.d. & 138.2 & 65.2 & 96.7 \\
& & 5.3 & 2.8 & 2.6 \\
Symbolically & mean s.d. & 148.7 & 68.9 & 99.8 \\
trephined & & 12.9 & 2.6 & 2.4 \\
\hline
\end{tabular}

TABLE IV

Classification results (Great Hungarian Plain dating from the time of the Hungarian conquest - X century)

\begin{tabular}{|c|c|c|c|c|c|c|c|c|c|}
\hline \multirow[b]{3}{*}{ Actual group } & \multirow[b]{3}{*}{$\mathrm{N}$} & \multicolumn{2}{|c|}{ Males } & \multirow[b]{3}{*}{$\mathrm{N}$} & Fem & ales & \multirow[b]{3}{*}{$\mathrm{N}$} & \multirow{2}{*}{\multicolumn{2}{|c|}{$\begin{array}{c}\text { Both sexes } \\
\text { Predicted group } \\
\text { membership }\end{array}$}} \\
\hline & & \multicolumn{2}{|c|}{$\begin{array}{l}\text { Predicted group } \\
\text { membership }\end{array}$} & & \multicolumn{2}{|c|}{$\begin{array}{c}\text { Predicted group } \\
\text { membership }\end{array}$} & & & \\
\hline & & Group 1 & Group 2 & & Group 1 & Group 2 & & Group 1 & Group 2 \\
\hline Group 1 (Non-trephined) & 52 & $38(73 \%)$ & $14(27 \%)$ & 34 & $33(97 \%)$ & $1(3 \%)$ & 86 & $71(85 \%)$ & $15(15 \%)$ \\
\hline Group 2 (Trephined) & 14 & $5(36 \%)$ & $9(64 \%)$ & 5 & $1(20 \%)$ & $4(80 \%)$ & 19 & $6(28 \%)$ & $13(72 \%)$ \\
\hline
\end{tabular}

In the XI century, when the population of the examined region were converted to Christianity, this tendency could not be observed as clearly as in the previous century (Szathmáry 1978, 1990). Thus, we can draw the conclusions that the interethnic connections between the various ethnic components of the early Hungarian population became intensive in the first century of Christianity in Hungary (i.e. in the XI century) as well as the custom of trephination was pushed into the background by Christianity for religious reasons. 


\section{REFERENCES}

Dear RE 1959. Principal component missing data method for multiple regression models system. Development Corporation, Tech Rep SP.86.

Dienes I 1972. The Hungarians cross the Carpathians, Corvina, Budapest.

Martin R 1928. Lehrbuch der Anthropologie. 2. Band, 2. Auflage, Fischer, Jena.

Szathmáry L 1978. Population-dynamische Untersuchungen der Population in Ungarn im 6-12 Jh. Ann Mus Debreceniensis de Friderico Déri Nom 1977: 143-165.

Szathmáry L 1980. The anthropological aspects of the relations of the Hungarians and the Bolgar-Turks in the 9-11th century Carpathian Basin. Congr Quintus Internat FennoUgristarum. Turku 2: 343.

Szathmáry L 1990. Demo-sociological change between the Pagan and the Early Christian Hungarians in the Upper Tisza region/NE Hungary. Congr Sept Internat Fenno-Ugristarum, Debrecen, Sess. Sect., D/I: 274-279. 